Article

\title{
Exploring Green Marketing Orientations toward Sustainability the Hospitality Industry in the COVID-19 Pandemic
}

\author{
Chun-Yi Ho ${ }^{1}$, Bi-Huei Tsai ${ }^{1}$, Chiao-Shan Chen ${ }^{2, *(D)}$ and Ming-Tsang Lu ${ }^{3, *}$ \\ 1 Department of Management Sciences, National Yang Ming Chiao Tung University, Hsinchu 1001, Taiwan; \\ jack.eagle@msa.hinet.net (C.-Y.H.); bhtsai@faculty.nctu.edu.tw (B.-H.T.) \\ 2 Research Center for Healthcare Industry Innovation, \\ National Taipei University of Nursing and Health Sciences, Taipei 112, Taiwan \\ 3 College of Management, National Taipei University of Business, Taipei 10051, Taiwan \\ * Correspondence: 8shan@ntunhs.edu.tw (C.-S.C.); mingtsang.lu@gmail.com (M.-T.L.); \\ Tel.: +886-2-2322-6325 (M.-T.L.)
}

check for updates

Citation: Ho, C.-Y.; Tsai, B.-H.; Chen, C.-S.; Lu, M.-T. Exploring Green Marketing Orientations toward Sustainability the Hospitality Industry in the COVID-19 Pandemic. Sustainability 2021, 13, 4348. https:// doi.org/10.3390/su13084348

Academic Editor: Andrea Pérez

Received: 18 February 2021

Accepted: 12 April 2021

Published: 14 April 2021

Publisher's Note: MDPI stays neutral with regard to jurisdictional claims in published maps and institutional affiliations.

Copyright: (c) 2021 by the authors. Licensee MDPI, Basel, Switzerland. This article is an open access article distributed under the terms and conditions of the Creative Commons Attribution (CC BY) license (https:// creativecommons.org/licenses/by/ $4.0 /)$.

\begin{abstract}
The effects of green marketing orientations for increasing the competitive advantage and improving the sustainability of the hospitality industry during the COVID-19 pandemic are receiving more attention. As the hospitality industry attempts to assimilate green marketing and move in the path of sustainable development, administrators need to expand their efforts for improving natural environmental orientation (NEO), market orientation, resource orientation, and brand orientation by applying their green marketing orientations to hospitality's strategies during the COVID-19 pandemic. Only few studies have examined the improvement of green marketing orientations. The objective of the research is to address this issue, applying the methods of fuzzy mixture MCDM (multiple criteria decision-making), with fuzzy decision-making trials and an evaluation laboratory (DEMATEL), and fuzzy DEMATEL-based ANP (fuzzy DANP) to inspect the feedback and interdependent issues among numerous elements/dimensions of green marketing orientations. In an uncertain environment, an empirical case study of the hospitality industry is shown to demonstrate the recommended combined approaches and, finally, to state the best enhancement approaches for administrators. This result shows that the natural environmental orientation is the most important factor.
\end{abstract}

Keywords: green marketing orientation; hospitality industry; COVID-19; MCDM (multiple criteria decision-making)

\section{Introduction}

Owing to the COVID-19 pandemic, the world economy was closed nearly every day. The large-scale travel restrictions and dissemination of COVID-19 continue to wreak havoc on the hospitality industry [1]. The strategies of travel and mobility restrictions, stay-athome orders, social distancing, and community lockdowns have caused the temporary closing of numerous hospitality businesses and reduced the request for businesses which could endure to operate significantly [2]. COVID-19 may have enduring consequences on the hospitality industry. Because of the COVID-19 global health crisis, the hospitality industry is "already facing collapse" and is "in a fight for survival" [3]. Stay-at-home orders and restrictions placed on travel issued via the governments led to sharp decline in hotel revenues and occupancies. Virtually all restaurants were requested to restrict operations to take-outs only. The reopening procedure has gradually started, and authorities have begun to ease limitations; such as, agreeing to let dine-in restaurants reopen at a decreased capacity through strict social distancing guidelines, and slowly decreasing restrictions on international and domestic travel. While vaccines are being manufactured in large quantities, the hospitality industry is gradually recovering. Therefore, effective marketing strategies are necessary for boosting users' confidence and to support businesses' recoveries in a timely manner after this public health crisis. The hospitality industry's sustainability 
can be solidified by addressing diverse green marketing orientations and taking phases to change adversity into opportunity.

In recent years, investigators have increasingly focused on green marketing or an environmental strategy that constitute key conceptions in management or marketing literatures [4-7]. Research recommends which green strategy improves value for businesses, but it needs integration into the business strategy if obligations towards sustainability are to be realized [8]. Moreover, numerous researchers stress the importance of implementing a green marketing strategy that could also yield strong profitability and a competitive advantage in the longer-term [9]. Regardless of these upstairs streams of green strategic approaches, empirically, little is known about relations between businesses' competitiveness and green marketing strategies. This is despite the fact that a prior study classifies relations among commercial performance and e- and green marketing [9]. Considering that competitive advantage is a long-term objective, its inspection under a research of green marketing strategic research creates an important research opportunity and gap.

Therefore, green marketing issues have got more attention [9]. In ecologically friendly environments, customers are now more conscious of their needs, and these are closely linked to green products [10]. Several green-conscious customers are gradually diverting to the purchase of environmentally friendly goods, rather than replacement goods, even with higher costs [10]. Green issues play a significant part in the hotel industry [11]. With each passing day, green issues have become topical for hotels, and customers are more conscious of the resource waste hotels produce (for example, disposable water, energy, and materials, or excessive consumption of consumables) and the environmental damage (for example, carbon emissions) they cause. Hence, hotel administrators have become progressively committed to green strategies [3]. To maintain and attain market success and competitive advantage, hotels need to be deliberate about positioning their green strategy as a core competence of the business and enhancing their managers' environmental consciousness [12-14]. Therefore, the importance of a green marketing orientation in commercial environments is generally conditioned by global diversity and growing economies.

Hotels are currently confronted with huge challenges in the COVID-19 pandemic [3]. Therefore, strategic marketing and activities in the hospitality industry are a critical responsibility; hence, more attention has been paid to green marketing orientations to enhance respective businesses' competitive advantages in the hospitality industry [13-16]. However, the implementation of green consciousness varies and requires considerable improvement; hotels need to address vagueness in green discourses and embark on green strategic development agendas. Regardless of the ubiquity of green narratives in green marketing literatures, there have been remarkably few empirical studies that guide businesses to operationalize and integrate green marketing in their business practices $[17,18]$. So far, green marketing has not focused on the green world's potential to enhance customers' quality of life or benefit the ecosystem $[19,20]$. The study addresses the need for a more combined investigation of green marketing orientation in relation to the concept of sustainability and using the hospitality industry to operationalize a green marketing business in the COVID-19 pandemic.

This paper proposes to explore the effects of green marketing orientations toward sustainability in the COVID-19 pandemic, with Taiwan's hospitality industry as a case study. This study is necessary, as it fills research gaps and investigates the creation of strategic estimation, green hotel and green marketing as inescapably helpful in reducing harmful substances and decreasing environmental dependence. Green marketing orientations are imprecise and subjective, changing based on practical experience specialists' views. The common multiple criteria decision-making (MCDM) models cannot continuously detect the complex influences of the different graded stages of the intricate elements of hotel environments. Moreover, MCDM models usually reflect specialists' interpretations of the strategic process and, therefore, may be inexact. Hence, interpretive differences need to be considered in the strategic process. The fuzzy number approach is a specialized method for determining vague and subjective specialists' decisions during a group strategy [21,22]. 
The fuzzy number has an agile border that reflects the subjectivity and vagueness of decisions [22,23]. Therefore, this research recommends a fuzzy MCDM model which can support specialists in making rational decisions in a situation.

The model primarily adopts the fuzzy number built in the decision-making trial and evaluation laboratory (DEMATEL) to create this assessment framework. Formerly, a fuzzy analytic network process (fuzzy DANP) was used to acquire a fuzzy influence network relation map (FINRM) and the fuzzy influence weights of the green marketing orientations and the relevant dimensions/elements. This suggested model conquers the limits of present strategic models and can be applied to evaluate topics which impact real-life for green marketing orientations toward sustainability. The case study of the hospitality industry in Taiwan is used to probe the interdependent variables which impact the hospitality industry and to recommend alternative green marketing orientations processes.

The main contributions of the paper are fourfold: primarily, the assessment of green marketing orientations is an administrative issue, considering the interdependent and interactional elements/dimensions involved. Based on the green marketing orientations framework, the study makes 4 dimensions and 12 elements to measure green marketing orientations assessments towards sustainability in the hospitality industry. Next, the study integrates the fuzzy DEMATEL and fuzzy DANP techniques to enhance a green marketing orientation assessment pattern which ranks comparative weights of green marketing orientation dimensions and elements in the COVID-19 pandemic. This suggested approach not only solves these interactions and dependences within elements and dimensions, but also provides more useful information that establishes a visual figure of cause and effect for enhanced green marketing plans. These empirical results demonstrate that the planned model for green marketing orientations toward sustainability improvement is effective in the COVID-19 pandemic. Next, this study shows that brand return on investment is the most important element of green marketing orientation towards sustainability. Green marketing orientations improve the sustainable development of the hospitality industry in the COVID-19 pandemic. Practically, green marketing orientation needs to be applied in the hospitality industry; this is not just a poster for sustainability in the COVID-19 pandemic. Green marketing orientations of the hospitality industry could transform under market pressures. Besides, managers come from dissimilar areas and there is the tendency for each person to have a dissimilar viewpoint. Hence, realizing green marketing approaches by systemic evaluation is needed in the COVID-19 pandemic. Finally, this research offers an executable green marketing orientation structure for administrators using previous experiences-from realizing the direction of the business plan to the execution of the approach, and, finally, attaining sustainability. This research found that strategic green marketing is one of the purposes of this industry. In line with the objectives, the market segments could be realized to make hotels more competitive. Notedly, the research can assist the hospitality industry make transformations to the environment by directly impacting their administrators.

This structure of the study is as follows: Section 2 is the review of existing papers; Section 3 states the methodology; Section 4 discusses the data and summarizes the empirical outcomes; Section 5 offers discussions and provides the conclusions, limitations and routes for future research.

\section{Literature Review}

The research concentrates on green marketing orientations, such as natural environment, market, resource, and brand orientations, as predictive and explanatory variables for green marketing orientations towards the sustainability of the hospitality industry in the COVID-19 pandemic. The investigation model proposes to aid decision evaluation for green marketing orientation issues. All serious assessment elements and dimensions hypothesized in the approach, and the dimensions and nature of their predictable relations to green marketing orientation issues, are stated as follows. 


\subsection{Green Marketing}

The tremendous development of green services or products in the marketplace in response to consumer needs has made green marketing strategies topical. The principles of green marketing change the values and attitudes of firms in order to fulfill consumers' needs $[20,24]$. Green promotion and green innovation are essential to green marketing strategies, as they affect customers' green consumption and firms' profitability [25]. Green marketing involves adapting the concept of environmental protection and technological innovations, including energy saving, green product design, and waste recycling [26-28]. Green marketing denotes any statement that improves services or products that will not harm the environment and can assist businesses in creating socially responsible corporate images [25]. Successful green promotion and green innovation enhances business performance. However, in current research, there is no systemic statement for implementing green marketing toward an industry's sustainability in the COVID-19 pandemic. There are arguments that some kinds of strategic orientation can realize some kinds of performance, but there is limited research on which kind is significant for the hospitality industry to make optimal choices. In the study, we reviewed natural environmental orientation, market orientation, resource orientation, and brand orientation as elements for green marketing orientations in order to estimate their place in the sustainability of the hospitality industry in the COVID-19 pandemic.

\subsection{Elements of Green Marketing Orientations for Evaluation}

\subsubsection{Natural Environmental Orientation}

This research extends former papers by suggesting a high-order structure of natural environmental orientation (NEO), collected from three core resources or initial order elements: commitment to nature, entrepreneurship, and corporate social responsibility as resources which cause to an NEO rather than state the NEO procedure (please see Table 1) [29-31]. Illustratively, the meaning is a preliminary point for investigating these factors of an NEO. On the other hand, this is also a preliminary viewpoint for prescribing the NEO optimum statement which has the highest chance of changing a business into a natural and ecologically oriented business [31]. Therefore, this current research implements the conceptualization in studying NEO dimensions in relation to commitment to the natural environment, entrepreneurship, and corporate social responsibility.

Table 1. Explanation of elements.

\begin{tabular}{cl}
\hline \multicolumn{1}{c}{ Dimensions/Elements } & \multicolumn{1}{c}{ Descriptions } \\
\hline Natural Environmental Orientation $\left(D_{1}\right)$ \\
\hline Commitment to nature $\left(e_{1}\right) \quad \begin{array}{l}\text { It refers to requirements for the hospitality industry to } \\
\text { take long-term reflections on sustainable strategies and } \\
\text { policies and to provide the corresponding resources } \\
\text { necessary for environmental protection. } \\
\text { It refers to the hotel demonstrating proactiveness and } \\
\text { taking risks with the corresponding resources necessary } \\
\text { for environmental protection. } \\
\text { It refers to the extent to which the hospitality industry } \\
\text { must go beyond economic concerns and give relevance } \\
\text { to the natural environment, indicating that a proactive } \\
\text { stance is needed for the corresponding resources } \\
\text { necessary for the environment. }\end{array}$ \\
\hline
\end{tabular}


Table 1. Cont.

\begin{tabular}{|c|c|}
\hline Dimensions/Elements & Descriptions \\
\hline \multicolumn{2}{|c|}{ Market Orientation $\left(D_{2}\right)$} \\
\hline Inter-functional coordination $\left(e_{4}\right)$ & $\begin{array}{l}\text { The coordinated adoption of firm resources in } \\
\text { establishing advantageous value for target consumers. }\end{array}$ \\
\hline Competitor orientation $\left(e_{5}\right)$ & $\begin{array}{l}\text { capabilities, and short-term weaknesses and strengths, } \\
\text { of both key potential competitors. }\end{array}$ \\
\hline Customer orientation $\left(e_{6}\right)$ & $\begin{array}{l}\text { It refers to the sufficient realization of one's objective } \\
\text { buyers to be able to continually establish advantageous } \\
\text { value for them. }\end{array}$ \\
\hline \multicolumn{2}{|c|}{ Resource Orientation $\left(D_{3}\right)$} \\
\hline Uniqueness $\left(e_{7}\right)$ & $\begin{array}{l}\text { It refers to resource uniqueness to the hospitality } \\
\text { industry. }\end{array}$ \\
\hline Synergy $\left(e_{8}\right)$ & $\begin{array}{l}\text { It refers to synergistic benefits across the hospitality } \\
\text { industry. }\end{array}$ \\
\hline Dynamism $\left(e_{9}\right)$ & $\begin{array}{l}\text { It refers to the improvement in the firm's dynamic } \\
\text { capabilities. }\end{array}$ \\
\hline \multicolumn{2}{|c|}{ Brand Orientation $\left(D_{4}\right)$} \\
\hline Brand positioning $\left(e_{10}\right)$ & $\begin{array}{l}\text { It refers to the brand forming a means of differentiation, } \\
\text { identification, and a guarantee of conformity to } \\
\text { consumers; therefore, every message related to the } \\
\text { brand is related to suitable value and competitive } \\
\text { positioning. }\end{array}$ \\
\hline Brand functionality $\left(e_{11}\right)$ & $\begin{array}{l}\text { It refers to how the brand facilitates difference through } \\
\text { competitors via corresponding detailed practical } \\
\text { benefits and attributes to consumers. }\end{array}$ \\
\hline Brand return on investment $\left(e_{12}\right)$ & $\begin{array}{l}\text { Brand return on investment is when the brand is } \\
\text { acknowledged as being censoriously significant in } \\
\text { leveraging return into financial rewards, and in realizing } \\
\text { its positional advantage in the market. }\end{array}$ \\
\hline
\end{tabular}

\subsubsection{Market Orientation}

In business culture, market orientation denotes a firm's disposition to continuously offer value advantage to its customers $[4,5,11,14,32-35]$. The concept of beneficial customer value needs a corporate promise to continuous information gathering about user necessities and competitor competence, as well as the provision of other important marketplace agents and authorities [36] presented in the three dimensions (customer orientation, competitor orientation, and inter-functional coordination) included in intelligence gathering, dissemination, and receptiveness to collected data. Besides, they posited that the three major dimensions have the same value. In summary, market orientation researchers detect a market-oriented business culture as important to excellent business performance. This paper uses these concepts to study the construction of market orientation elements that include inter-functional coordination, competitor orientation, and customer orientation (please see Table 1).

\subsubsection{Resource Orientation}

Resource orientation is mainly internally oriented, meaning its focus lies with the deployment and development of sole hotel resources [3,37]. Based on the resource-based view, it is a sole resource according to the fact that it is heterogeneous and immobile [37]. Resource orientation is applied in research and it estimates the degree to which a hotel is concerned with the transformation of unique and valuable organizational resources. It proposes to explain how a hotel's resources drive its competitive performance $[38,39]$. Resource orientation is composed of three dimensions: uniqueness (resource uniqueness to the hotel); synergy (synergistic benefits across the hotel); and dynamism (the improvement 
of the hotel's dynamic competences) [38,39]. The final purpose of resource orientation is to make value for the business via positioning costly to imitate and sole resource bundles for the purpose of counteracting pressures and utilizing the opportunities of the environment [38]. Therefore, managers of the hospitality industry can use the resource base to counteract any pressures, or to utilize any opportunities which increase in the external setting. Resource orientation defines the level to which a hotel's applications reflect its resource base. Dynamism defines the practice of resources as causes for the hotel to adapt to and learn [40]. Therefore, based on existing research, this study implements the concept of resource orientation elements with uniqueness, synergy, and dynamism.

\subsubsection{Brand Orientation}

Brand orientation is a way to structure a brand in terms of brand equity; this is established by an interplay between external and internal stakeholders $[6,20,41]$. This paper considers brands as the hub around which business processes operate. It notes that conscious brand management, core competence, and brand building are intimately related to business enhancement and financial performance. Since green marketing conceptions are on the rise, green concepts have been applied to numerous brand positioning strategies [20,41]. Globally, many corporations are adjusting their green marketing strategies; for instance, by ensuring that their interests address the needs of green products and green consumers, in line with existing regulations [42], or by amending their business philosophy $[20,43]$. Generally, successful green marketing with brand orientations contains the brand positioning, brand functionality and brand return on investment [44,45]. Managers in the hospitality industry mainly need to be able to apply functional attributes to green products and prove their benefits within the environmental protection concept. Lastly, they need to prove the benefits that apply to the brand $[20,46]$. Changes in the patterns of green marketing are important for most administrators, and most hotel industries are selling and developing novel green products and incorporating green policies into their strategies or marketing. Shrivastava [47] determined that, as corporations proceed to combine the conception of green into business products, they can acquire benefits such as brand return on investment, brand functionality, and brand positioning, which increase sales revenue, accelerate entry into new markets, improve competitive advantage, and improve corporate image [45]. Hence, when existing research conceptualized the construction of brand orientation elements, they included brand positioning, brand functionality, and brand return on investment.

Our assessment framework focuses on green marketing orientations (natural environmental orientation, market orientation, resource orientation, and brand orientation) that significantly influence green marketing orientations toward sustainability. There are also lower-level factors and associated elements considered in previous studies. Our entire assessment structure, comprising the elements and dimensions, is presented in Table 1.

\section{Methods}

The mixture MCDM model assembled with fuzzy, as identified in literature, is considered to be an appropriate method for examining green marketing orientations in the hospitality industry in the COVID-19 pandemic. It can be employed as a case for managers to develop green marketing orientation estimation approaches per element. This mixture of MCDM with fuzzy pattern's systematic methods is not only used for choosing/ranking but also to explain the problems among different elements and the dimensions for green marketing orientations in the hospitality industry. According to the fuzzy INRM, this method has a tendency to divert through selection/ranking to enhancement $[8,23,48]$.

This fuzzy DEMATEL approach was applied to set up a total influence relations matrix and to survey the cause and effect and interrelationships among parameters extracted by distinct elements. Formerly, we mixed the impact relations matrix acquired by the fuzzy DEMATEL approach to set up the based ANP [49], and determined the fuzzy weights of influence for per dimension/factor $[8,22,23,50,51]$. 


\subsection{Fuzzy DEMATEL}

- $\quad$ Stage 1: Express direct influence matrix with fuzzy numbers.

According to the varied fuzzy numbers of experts' point of views via linguistics, through the language of nature, the direct influence which is the element $i$ 's influence on element $j$ is denoted with fuzzy score $\widetilde{c}_{i j}=\left(l_{i j}, m_{i j}, r_{i j}\right)$. The direct relations matrix $\widetilde{\boldsymbol{C}}=\left[\widetilde{c}_{i j}\right]_{n \times n}=\left[\left(l_{i j}, m_{i j}, r_{i j}\right)\right]_{n \times n}$ is acquired.

$$
\widetilde{\boldsymbol{C}}=\left(\begin{array}{ccccc}
\widetilde{c}_{11} & \cdots & \widetilde{c}_{1 j} & \cdots & \widetilde{c}_{1 n} \\
\vdots & & \vdots & & \vdots \\
\widetilde{c}_{i 1} & \cdots & \widetilde{c}_{i j} & \cdots & \widetilde{c}_{i n} \\
\vdots & & \vdots & & \vdots \\
\widetilde{c}_{n 1} & \cdots & \widetilde{c}_{n j} & \cdots & \widetilde{c}_{n n}
\end{array}\right)_{m \times m}
$$

where diagonal triangular fuzzy memberships are considered as triangular fuzzy numbers: $\widetilde{c}_{11}=\ldots=\widetilde{c}_{i i}=\ldots=\widetilde{c}_{n n}=(0,0,0) ; \widetilde{c}_{i j}=\left(l_{i j}, m_{i j}, r_{i j}\right), i \neq j$ and $i, j \in\{1,2, \ldots, n\}$.

- Stage 2: Normalize this matrix of direct influence.

According to the direct $\widetilde{C}$, influence matrix, the normalized $\widetilde{Z}$, the matrix of direct relations is attained by Equations (1) and (2).

$$
\widetilde{\boldsymbol{B}}=u \otimes \widetilde{\boldsymbol{C}}
$$

as $u=\min \left\{1 / \max _{i} \sum_{j=1}^{n} r_{i j}, 1 / \max _{j} \sum_{i=1}^{n} r_{i j}\right\}, i, j \in\{1,2, \ldots, n\}$.

- $\quad$ Stage 3: Calculate the matrix of total influence.

As the matrix $\widetilde{\boldsymbol{B}}$ of normalized direct influence is attained, $\widetilde{\boldsymbol{P}}=\left(\boldsymbol{P}^{l}, \boldsymbol{P}^{m}, \boldsymbol{P}^{r}\right)$, the matrix of FINRM can be acquired applying Equation (3), in which $\boldsymbol{F}$ indicates this identity matrix.

$$
\widetilde{\boldsymbol{P}}=\widetilde{\boldsymbol{B}}+\widetilde{\boldsymbol{B}}^{2}+\widetilde{\boldsymbol{B}}^{3}+\ldots+\widetilde{\boldsymbol{B}}^{h}=\widetilde{\boldsymbol{B}}\left(\boldsymbol{F}+\widetilde{\boldsymbol{B}}+\widetilde{\boldsymbol{B}}^{2}+\ldots+\widetilde{\boldsymbol{B}}^{h-1}\right)\left[(\boldsymbol{F}-\widetilde{\boldsymbol{B}})(\boldsymbol{F}-\widetilde{\boldsymbol{B}})^{-1}\right]=\widetilde{\boldsymbol{B}}\left(\boldsymbol{F}-\widetilde{\boldsymbol{B}}^{h}\right)(\boldsymbol{F}-\widetilde{\boldsymbol{B}})^{-1}
$$

Formerly, $\widetilde{\boldsymbol{P}}=\widetilde{\boldsymbol{B}}(\boldsymbol{F}-\widetilde{\boldsymbol{B}})^{-1}$, as $h \rightarrow \infty$, we could ensure

$$
\widetilde{\boldsymbol{B}}^{h}=[0]_{n \times n}
$$

where $\widetilde{\boldsymbol{B}}=\left[\widetilde{b}_{i j}\right]_{n \times n}=\left[\left(b_{i j}^{l}, b_{i j}^{m}, b_{i j}^{r}\right)\right]_{n \times n^{\prime}} 0 \leq b_{i j}^{l}, b_{i j}^{m}, b_{i j}^{r}<1,0<\sum_{j=1}^{n} b_{i j}^{r} \leq 1,0<\sum_{i=1}^{n} b_{i j}^{r} \leq 1$. If one column or row of summation is at least equal to 1 within $\sum_{j=1}^{n} b_{i j}^{r}$ and $\sum_{i=1}^{n} b_{i j}^{r}$, we are able to agree: $\lim _{h \rightarrow \infty}\left(\left[b_{i j}^{r}\right]_{n \times n}\right)^{h}=\lim _{h \rightarrow \infty}\left(\boldsymbol{B}^{r}\right)^{h}=[0]_{n \times n}$. Likewise, we can also agree: $\lim _{h \rightarrow \infty}\left(\left[b_{i j}^{m}\right]_{n \times n}\right)^{h}=\lim _{h \rightarrow \infty}\left(\boldsymbol{B}^{m}\right)^{h}=[0]_{n \times n}$ and $\lim _{h \rightarrow \infty}\left(\left[b_{i j}^{l}\right]_{n \times n}\right)^{h}=\lim _{h \rightarrow \infty}\left(\boldsymbol{B}^{l}\right)^{h}=[0]_{n \times n}$. Then $\widetilde{\boldsymbol{P}}=\left[\widetilde{p}_{i j}\right]$ can be achieved.

- $\quad$ Stage 4: Exploring the outcomes.

In the summation of columns, $\sum_{i=1}^{n} \widetilde{p}_{i j}=\widetilde{p}_{\cdot j}=\widetilde{v}_{j}$ and the sum of rows $\sum_{j=1}^{n} \widetilde{p}_{i j}=\widetilde{p}_{i}=\widetilde{z}_{i}$ are separately expressed as vector $\widetilde{\boldsymbol{v}}=\left(\widetilde{\boldsymbol{v}}_{1}, \ldots, \widetilde{\boldsymbol{v}}_{j}, \ldots, \widetilde{\boldsymbol{v}}_{n}\right)^{\prime}$ and vector $\widetilde{\boldsymbol{z}}=\left(\widetilde{\boldsymbol{z}}_{1}, \ldots, \widetilde{\boldsymbol{z}}_{i}, \ldots, \widetilde{z}_{n}\right)^{\prime}$ via applying Equation (4) to Equation (6). Make $i, j \in\{1,2, \ldots, n\}$ and $i=j$; this vector of horizontal axis $(\widetilde{z}+\widetilde{v})$ is used by raising $\widetilde{z}$ to $\widetilde{v}$; this illustrates the importance of the element. Relevantly, the vector $(\widetilde{z}-\widetilde{v})$ of vertical axis is made via deducting $\widetilde{z}$ through $\widetilde{v}$, segregating elements into an effect group and a cause group. Usually, if $(\widetilde{\boldsymbol{z}}-\widetilde{\boldsymbol{v}})$ is positive, 
the element is set for this cause cluster. Besides, as vector $(\widetilde{z}-\widetilde{v})$ is negative, this element is set as the influence cluster. Consequently, this causal map could be attained via charting the vectors' $(\widetilde{z}+\widetilde{\boldsymbol{v}}, \widetilde{z}-\widetilde{\boldsymbol{v}})$ dataset, proposing a useful approach to make a decision.

$$
\begin{gathered}
\widetilde{\boldsymbol{P}}=\left[\widetilde{p}_{i j}\right]_{n \times n^{\prime}}, i, j=1,2, \ldots, n \\
\widetilde{\boldsymbol{v}}=\left[\sum_{i=1}^{n} \widetilde{t}_{i j}\right]_{1 \times n}^{\prime}=\left[\widetilde{t}_{. j}\right]_{n \times 1}=\left(\widetilde{\boldsymbol{v}}_{1}, \ldots, \widetilde{\boldsymbol{v}}_{j}, \ldots, \widetilde{\boldsymbol{v}}_{n}\right)^{\prime} \\
\widetilde{\boldsymbol{z}}=\left[\sum_{j=1}^{n} \widetilde{t}_{i j}\right]_{n \times 1}=\left[\widetilde{t}_{i \cdot}\right]_{n \times 1}=\left(\widetilde{\boldsymbol{z}}_{1}, \ldots, \widetilde{\boldsymbol{z}}_{i}, \ldots, \widetilde{\boldsymbol{z}}_{n}\right)^{\prime}
\end{gathered}
$$

where the $\widetilde{v}$ and $\widetilde{z}$ vectors indicate these summations of the columns and rows through the total-influence matrix $\widetilde{\boldsymbol{P}}=\left[\widetilde{p}_{i j}\right]_{n \times n^{\prime}}$ separately, and the application of a superscript denotes transpose.

\subsection{Fuzzy DANP}

DANP has been demonstrated to be more beneficial than ANP in actual living. Though ANP can theoretically be used for the handling of interdependencies [49], it is wise to adopt DEMATEL to create a relationship of influence through the unweighted supermatrix and weighted supermatrix. In the past, DANP's weights of influence could be acquired. Hence, in this approach, fuzzy DEMATEL is initially used to acquire the total influence matrix with defuzzied, then it is normalized using criteria to catch the influence weights of criteria and elements. Hence, DANP has the strength of the DEMATEL and ANP approaches, and can effectually resolve these dependence feedback and issues associated with the interrelationship among these dimensions/elements $[8,23]$.

- $\quad$ Stage 1: Developing the unweighted supermatrix.

Normalize the total influence degree of this fuzzy total influence matrix, $\widetilde{\boldsymbol{P}}$, that apply fuzzy DEMATEL [10]. See Equation (7)

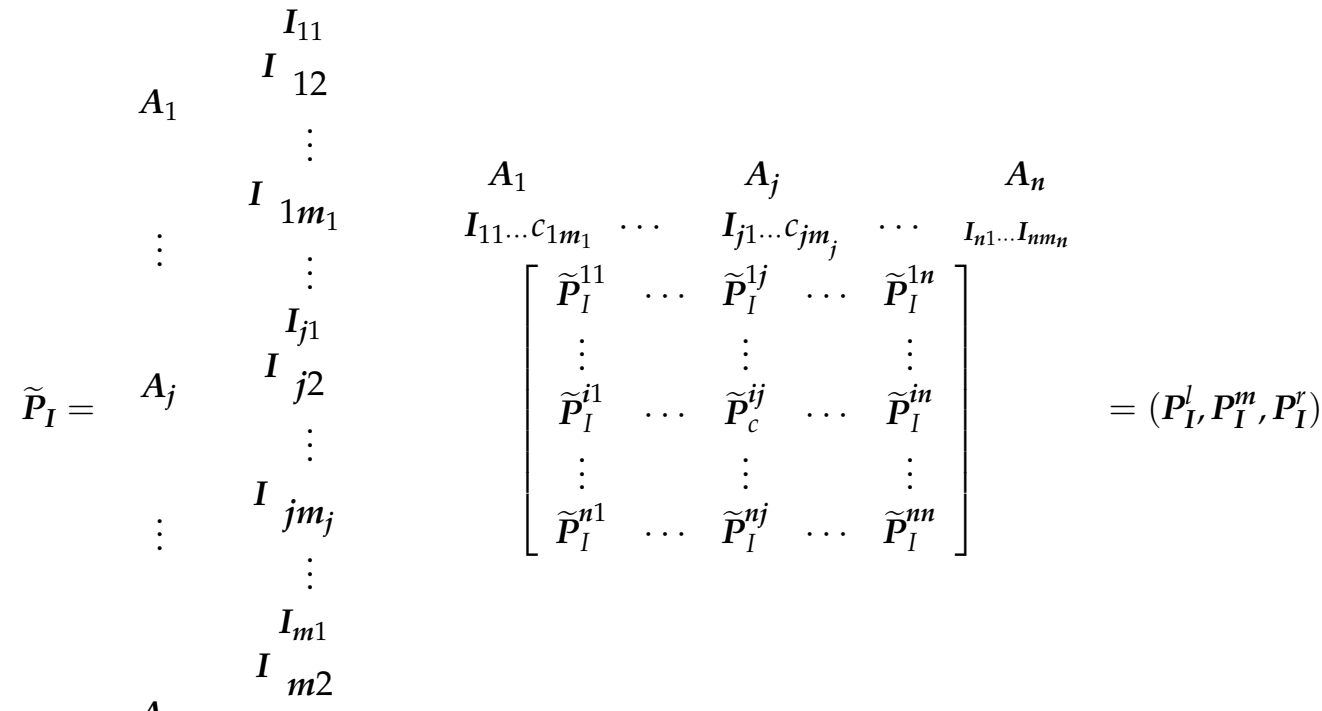

$$
\begin{aligned}
& \mathbf{I}_{n m_{m}}
\end{aligned}
$$


Then, normalize $\boldsymbol{P}_{I}$ through the total degree of effect and obtain $\boldsymbol{P}_{I}^{\alpha}$, see Equation (8);

$$
\begin{aligned}
& \begin{array}{rrr} 
& \boldsymbol{I}_{11} \\
& \quad \boldsymbol{I}_{12} \\
A_{1} & &
\end{array}
\end{aligned}
$$

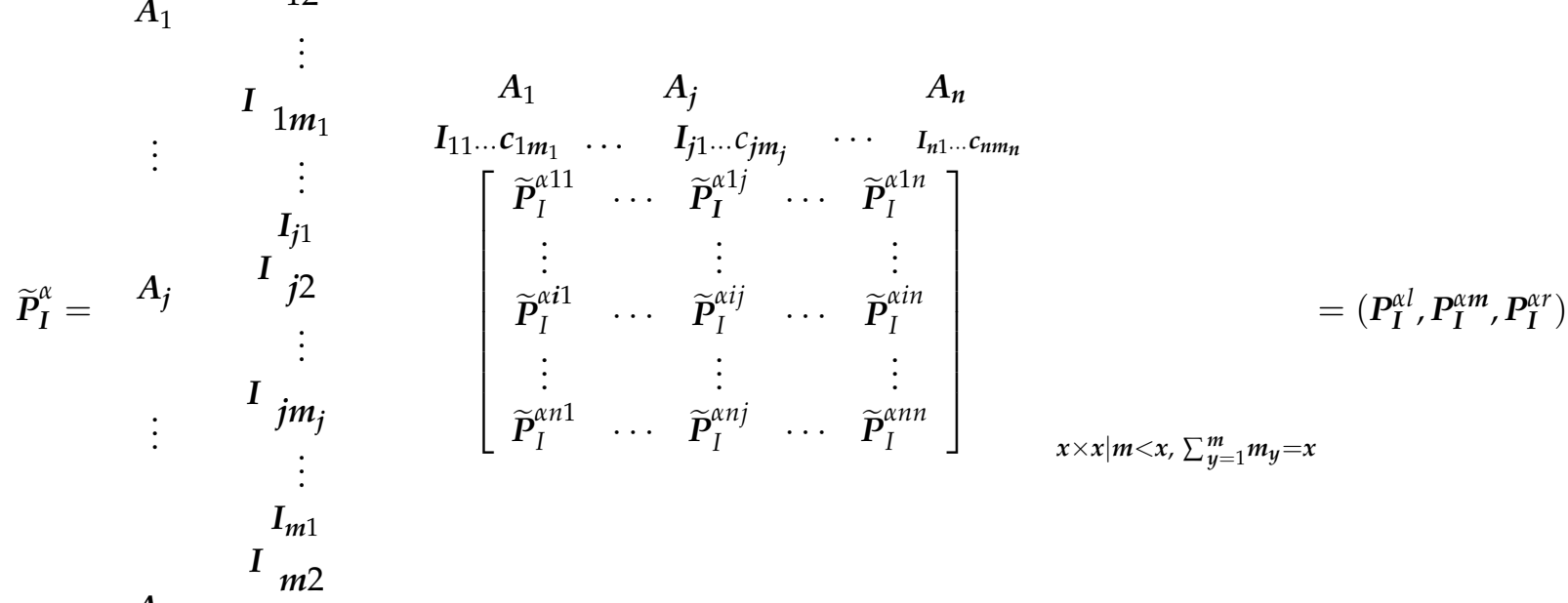

$$
\begin{aligned}
& A_{n}
\end{aligned}
$$

This total influence matrix has been normalized into a supermatrix followed by these inter dependent relations in a group to obtain this unweighted supermatrix. See Equation (9).

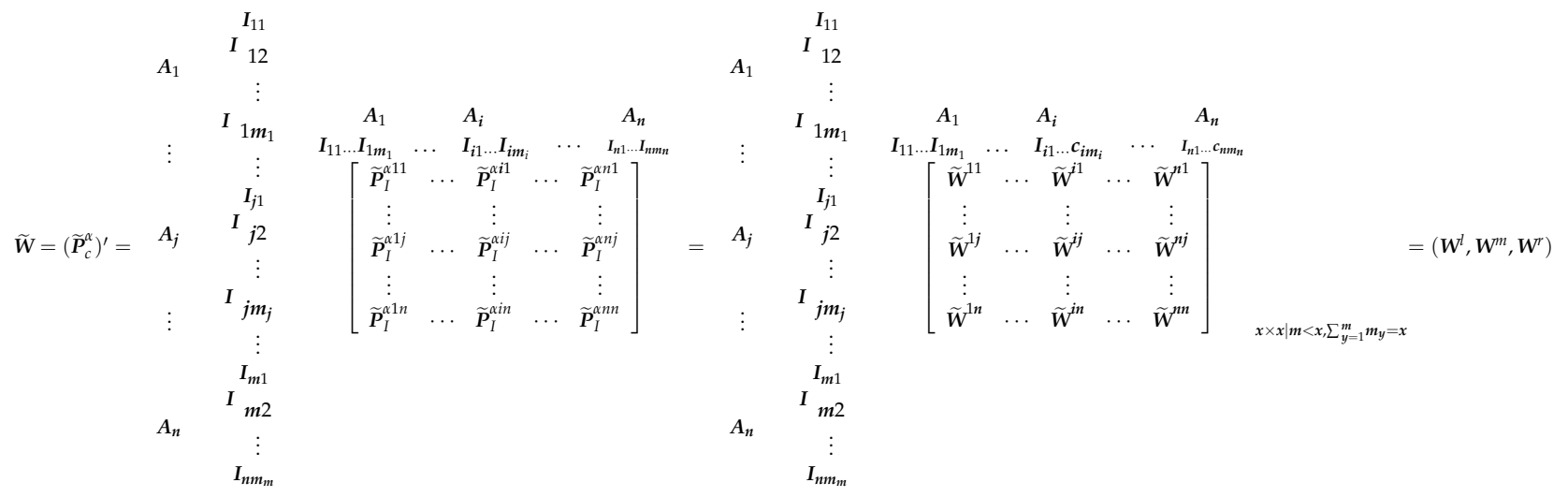

- $\quad$ Stage 2: Achieve the supermatrix weight.

The Equation (10) is shown the total influence relations matrix of the criteria matrix, $\widetilde{\boldsymbol{P}}_{A}$. The criteria for matrix $\widetilde{\boldsymbol{P}}_{A}$ are normalized through this total degree of influence to attain $\boldsymbol{P}_{I}^{\alpha}$. Expressed in Equation (11).

$$
\widetilde{\boldsymbol{P}}_{A}=\left[\begin{array}{ccccc}
\widetilde{p}_{A}^{11} & \cdots & \widetilde{p}_{A}^{1 j} & \cdots & \widetilde{p}_{A}^{1 n} \\
\vdots & & \vdots & & \vdots \\
\widetilde{p}_{A}^{i 1} & \cdots & \tilde{p}_{A}^{i j} & \cdots & \widetilde{p}_{A}^{i n} \\
\vdots & & \vdots & & \vdots \\
\widetilde{p}_{A}^{n 1} & \cdots & \tilde{p}_{A}^{n j} & \cdots & \widetilde{p}_{A}^{n n}
\end{array}\right]=\left(\boldsymbol{P}_{A}^{l}, \boldsymbol{P}_{A}^{m}, \boldsymbol{P}_{A}^{r}\right)
$$




$$
\boldsymbol{P}_{A}^{\alpha l}=\left[\begin{array}{ccccc}
p_{A}^{11 l} / d_{1}^{l} & \cdots & p_{A}^{1 j l} / d_{1}^{l} & \cdots & p_{A}^{1 n l} / d_{1}^{l} \\
\vdots & & \vdots & & \vdots \\
p_{A}^{i 1 l} / d_{i}^{l} & \cdots & p_{A}^{i j l} / d_{i}^{l} & \cdots & p_{A}^{i n l} / d_{i}^{l} \\
\vdots & & \vdots & & \vdots \\
p_{A}^{n 1 l} / d_{n}^{l} & \cdots & p_{A}^{n j l} / d_{n}^{l} & \cdots & p_{A}^{n n l} / d_{n}^{l}
\end{array}\right]_{m \times m}=\left[\begin{array}{ccccc}
p_{A}^{\alpha 11 l} & \cdots & p_{A}^{\alpha 1 j l} & \cdots & p_{A}^{\alpha 1 n l} \\
\vdots & & \vdots & & \vdots \\
p_{A}^{\alpha i 1 l} & \cdots & p_{A}^{\alpha i j l} & \cdots & p_{A}^{\alpha i n l} \\
\vdots & & \vdots & & \vdots \\
p_{A}^{\alpha n 1 l} & \cdots & p_{A}^{\alpha n j l} & \cdots & p_{A}^{\alpha n n l}
\end{array}\right]_{m \times m}
$$

We can attain matrix $\boldsymbol{P}_{A}^{\alpha m}, \boldsymbol{P}_{A}^{\alpha r}$.

After that, multiply $\boldsymbol{P}_{A}^{\alpha}$ from the unweighted supermatrix to obtain the weight of supermatrix. Shown as Equation (12). The weighted supermatrix, $\boldsymbol{W}^{\alpha r}$ and $\boldsymbol{W}^{\alpha m}$, are acquired too.

$$
\begin{aligned}
& \boldsymbol{W}^{\alpha l}=\boldsymbol{P}_{A}^{\alpha l} \boldsymbol{W}^{l}= \\
& {\left[\begin{array}{ccccc}
p_{A}^{\alpha 11 l} \times \boldsymbol{W}^{11 l} & \cdots & p_{A}^{\alpha i 1 l} \times \boldsymbol{W}^{i 1 l} & \cdots & p_{A}^{\alpha n 1 l} \times \boldsymbol{W}^{n 1 l} \\
\vdots & & \vdots & & \vdots \\
p_{A}^{\alpha 1 j l} \times \boldsymbol{W}^{1 j l} & \cdots & p_{A}^{\alpha i j l} \times \boldsymbol{W}^{i j l} & \cdots & p_{A}^{\alpha n j l} \times \boldsymbol{W}^{n j l} \\
\vdots & & \vdots & & \vdots \\
p_{A}^{\alpha 1 n l} \times \boldsymbol{W}^{1 n l} & \cdots & p_{A}^{\alpha i n l} \times \boldsymbol{W}^{i n l} & \cdots & p_{A}^{\alpha n n l} \times \boldsymbol{W}^{n n l}
\end{array}\right]}
\end{aligned}
$$

- $\quad$ Stage 3: Limit the fuzzy weighted super-matrix.

Previously, the influence weights of each element were acquired by $\lim _{x \rightarrow \infty}\left(\boldsymbol{W}^{\alpha r}\right)^{x}$, $\lim _{x \rightarrow \infty}\left(\boldsymbol{W}^{\alpha m}\right)^{x}$, and $\lim _{x \rightarrow \infty}\left(\boldsymbol{W}^{\alpha l}\right)^{x}$ respectively; the weights of influence ANP need to be denoted and attained by the limitation supermatrix $\boldsymbol{W}^{\alpha r}, \boldsymbol{W}^{\alpha m}$, and $\boldsymbol{W}^{\alpha l}$ with power $x$ separately. Sunsequently, we adjust DANP weights of influence based on the matrix $\boldsymbol{P}^{l}, \boldsymbol{P}^{m}$, and $\boldsymbol{P}^{r}$ ratios in $\widetilde{\boldsymbol{P}}=\left(\boldsymbol{P}^{l}, \boldsymbol{P}^{m}, \boldsymbol{P}^{r}\right)$ or based on the total degree ratios of effect $(\widetilde{\boldsymbol{z}}+\widetilde{\boldsymbol{v}})$. We set sum equal 1 with fuzzy number of triangles for medium in the weights of influence, and we regulated high bound and low bound ratios. Previously, DANP with triangle fuzzy numbers needed to be acquired.

\section{Results}

The empirical case focused on the hospitality industry in Taiwan in the COVID-19 pandemic is provided to show the application of this recommend fuzzy MCDM pattern, with the goal of choosing and evaluating the best approaches. The approach is able to assist managers in their governance to better handle matters toward sustainability of the hospitality industry in the COVID-19 pandemic through the green marketing orientation structure, and to realize the enhancement and improvement for distinct dimensions/elements.

\subsection{Data Collection}

Through these literature reviews and experts' opinions, with at least four focus groups lasting at least $60 \mathrm{~min}$, we present four dimensions and confirm 12 elements which impact the green marketing orientations toward sustainability in the COVID-19 pandemic. After that, we built up a survey of DEMATEL. For the DEMATEL questionnaire, we used the 5 Likert scales, which settled the scale through "very high influence (4)" to "lack of influence (0)". Lastly, the surveys of the DEMATEL questionnaire were confirmed by experts. The study used the proposed approach in the hospitality industry in Taiwan as a case. All data were collected from 24 experts. To make sure of the reliability of these experts, this research established personal face-to-face interviews to make sure which definitions of the questions inquired could be realized. Those experts are researchers and upper administration level, with an average working experience in the hospitality industry of more than 10 years, and the related info of the experts is shown as Table 2. They agreed that all factors are crucial and comprehensive, showing that the factors need to be applied into this study. 
For consistency, the statistical significance confidence is $98.769 \%$ in consensus; that is greater than $95 \%$, and the error gap is less than $5 \%$ in $1.231 \%$ in this approach. As this consistency ratio is less than the significance value- the threshold is usually set to $5 \%$ it can be determined that the 24 specialists' replies attained an appropriate consistency and consensus.

Table 2. The information of experts.

\begin{tabular}{cc}
\hline Category & Number of Experts \\
\hline Education level & \\
\hline Bachelor. & 5 \\
Master & 9 \\
Ph.D & 10 \\
\hline Years of working experiences & 4 \\
\hline Between 10 and 14 years & 8 \\
Between 15 and 19 years & 12 \\
More than 20 years & \\
\hline Job level & 10 \\
\hline Researchers in related industry & 14 \\
\hline Top managers in hospitality industry & \\
\hline
\end{tabular}

\subsection{Setting up the FINRM via the Fuzzy DEMATEL Approach}

We applied the fuzzy DEMATEL method to establish the estimation framework in this study for the inspection of a sustainability strategy within the green marketing orientations framework from four dimensions with 12 elements. The matrix $P$ of total influence gained for these elements and dimensions are shown in Tables 3-5, according to the application of expert surveys. The experts' thoughts and perspectives were acquired by 12 elements. The relations as fields of influence are associated to the numerous dimensions and elements as illustrated in Tables 3 and 5. According to the total influence for each dimension (see Table 4), "market orientation" $\left(D_{2}\right)$ has the strongest relational influence. In contrast, "resource orientation" $\left(D_{3}\right)$ has the least influence. According to the influence of net, we also find that "market orientation" $\left(D_{2}\right)$ has the most influence of net on the other criteria, and the "brand orientation" $\left(D_{4}\right)$ has the weakest influence.

Table 3. Total fuzzy influential relationship matrix.

\begin{tabular}{ccccc}
\hline Dimensions & $\boldsymbol{D}_{\mathbf{1}}$ & $\boldsymbol{D}_{\mathbf{2}}$ & $\boldsymbol{D}_{\mathbf{3}}$ & $\boldsymbol{D}_{\mathbf{4}}$ \\
\hline Natural environmental & 0.330 & 0.329 & 0.338 & 0.345 \\
orientation $\left(D_{1}\right)$ & $(0.184,0.289,0.515)$ & $(0.183,0.289,0.516)$ & $(0.192,0.299,0.525)$ & $(0.194,0.306,0.536)$ \\
Market orientation $\left(D_{2}\right)$ & 0.364 & 0.330 & 0.351 & 0.371 \\
& $(0.211,0.324,0.559)$ & $(0.184,0.289,0.516)$ & $(0.198,0.311,0.543)$ & $(0.219,0.332,0.563)$ \\
Resource orientation $\left(D_{3}\right)$ & 0.333 & 0.316 & 0.295 & 0.333 \\
Brand orientation $\left(D_{4}\right)$ & $(0.179,0.291,0.529)$ & $(0.164,0.275,0.509)$ & $(0.147,0.255,0.485)$ & $(0.179,0.293,0.527)$ \\
& 0.331 & 0.307 & 0.302 & 0.310 \\
\end{tabular}

The influence of all elements per element are illustrated in Table 5. Table 6 shows these relations and their degree of influence by direct or indirect contrasts, in correspondence to other elements. "inter-functional coordination" $\left(e_{4}\right)$ is the most significant element to watch; "uniqueness" $\left(e_{7}\right)$ influences the other elements the least. Besides, Table 6 also illustrates that "competitor orientation" $\left(e_{5}\right)$ has the strongest influence on the other elements, as "brand return on investment" $\left(e_{12}\right)$ is the most influential in comparison to the other elements. 
Table 4. The sum of the effects for each dimension.

\begin{tabular}{ccccc}
\hline Dimensions & $\widetilde{z}_{i}$ & $\widetilde{\boldsymbol{v}}_{\boldsymbol{i}}$ & $\widetilde{\boldsymbol{z}}_{\boldsymbol{i}}+\widetilde{\boldsymbol{v}}_{\boldsymbol{i}}$ & $\widetilde{\boldsymbol{z}}_{\boldsymbol{i}}-\widetilde{\boldsymbol{v}}_{\boldsymbol{i}}$ \\
\hline Natural environmental & 1.343 & 1.358 & 2.701 & -0.015 \\
orientation $\left(D_{1}\right)$ & $(0.753,1.183,2.092)$ & $(0.755,1.194,2.125)$ & $(1.508,2.377,4.217)$ & $(-0.001,-0.011,-0.032)$ \\
Market orientation $\left(D_{2}\right)$ & 1.416 & 1.283 & 2.699 & 0.133 \\
& $(0.812,1.256,2.181)$ & $(0.688,1.121,2.039)$ & $(1.500,2.377,4.220)$ & $(0.123,0.135,0.142)$ \\
Resource orientation $\left(D_{3}\right)$ & 1.278 & 1.286 & 2.564 & -0.008 \\
Brand orientation $\left(D_{4}\right)$ & $(0.669,1.115,2.050)$ & $(0.683,1.129,2.046)$ & $(1.352,2.243,4.096)$ & $(-0.014,-0.014,0.003)$ \\
& $(0.646,1.092,2.011)$ & $(0.754,1.201,2.124)$ & $(1.400,2.293,4.135)$ & $(-0.108,-0.109,-0.113)$ \\
\hline
\end{tabular}

Table 5. The fuzzy total influence relationship matrix for each element.

\begin{tabular}{ccccccccccccc}
\hline Elements & $\boldsymbol{P}_{\mathbf{1}}$ & $\boldsymbol{P}_{\mathbf{2}}$ & $\boldsymbol{P}_{\mathbf{3}}$ & $\boldsymbol{P}_{\mathbf{4}}$ & $\boldsymbol{P}_{\mathbf{5}}$ & $\boldsymbol{P}_{\mathbf{6}}$ & $\boldsymbol{P}_{\mathbf{7}}$ & $\boldsymbol{P}_{\mathbf{8}}$ & $\boldsymbol{P}_{\mathbf{9}}$ & $\boldsymbol{P}_{\mathbf{1 0}}$ & $\boldsymbol{P}_{\mathbf{1 1}}$ & $\boldsymbol{P}_{\mathbf{1 2}}$ \\
\hline$e_{1}$ & 0.299 & 0.366 & 0.381 & 0.369 & 0.290 & 0.384 & 0.328 & 0.372 & 0.352 & 0.355 & 0.343 & 0.388 \\
$e_{2}$ & 0.366 & 0.279 & 0.378 & 0.364 & 0.278 & 0.370 & 0.342 & 0.340 & 0.367 & 0.343 & 0.339 & 0.373 \\
$e_{3}$ & 0.323 & 0.309 & 0.266 & 0.334 & 0.258 & 0.318 & 0.299 & 0.302 & 0.343 & 0.321 & 0.311 & 0.336 \\
$e_{4}$ & 0.431 & 0.405 & 0.432 & 0.341 & 0.343 & 0.444 & 0.386 & 0.394 & 0.421 & 0.415 & 0.407 & 0.458 \\
$e_{5}$ & 0.352 & 0.342 & 0.358 & 0.357 & 0.233 & 0.379 & 0.326 & 0.322 & 0.355 & 0.363 & 0.346 & 0.383 \\
$e_{6}$ & 0.322 & 0.307 & 0.330 & 0.331 & 0.271 & 0.269 & 0.299 & 0.321 & 0.332 & 0.310 & 0.303 & 0.358 \\
$e_{7}$ & 0.303 & 0.290 & 0.306 & 0.319 & 0.251 & 0.312 & 0.226 & 0.294 & 0.286 & 0.293 & 0.284 & 0.319 \\
$e_{8}$ & 0.365 & 0.342 & 0.362 & 0.343 & 0.275 & 0.345 & 0.335 & 0.266 & 0.321 & 0.348 & 0.328 & 0.386 \\
$e_{9}$ & 0.357 & 0.317 & 0.353 & 0.359 & 0.279 & 0.364 & 0.312 & 0.344 & 0.275 & 0.349 & 0.315 & 0.377 \\
$e_{10}$ & 0.321 & 0.313 & 0.310 & 0.316 & 0.259 & 0.314 & 0.287 & 0.297 & 0.308 & 0.251 & 0.302 & 0.359 \\
$e_{11}$ & 0.338 & 0.312 & 0.343 & 0.313 & 0.259 & 0.316 & 0.286 & 0.295 & 0.295 & 0.318 & 0.244 & 0.352 \\
$e_{12}$ & 0.351 & 0.347 & 0.343 & 0.353 & 0.289 & 0.347 & 0.306 & 0.307 & 0.335 & 0.335 & 0.330 & 0.296 \\
\hline
\end{tabular}

Table 6. The sum of the effects matrix for each element.

\begin{tabular}{|c|c|c|c|c|}
\hline Elements & $\tilde{z}_{i}$ & $\widetilde{\boldsymbol{v}}_{i}$ & $\widetilde{z}_{i}+\widetilde{v}_{i}$ & $\widetilde{z}_{i}-\widetilde{v}_{i}$ \\
\hline$e_{1}$ & $\begin{array}{l}4.228(2.471, \\
3.741,6.471)\end{array}$ & $\begin{array}{l}4.129(2.282, \\
3.620,6.485)\end{array}$ & $\begin{array}{r}8.357(4.754 \\
7.360,12.956)\end{array}$ & $\begin{array}{c}0.099(0.189 \\
0.121,-0.013)\end{array}$ \\
\hline$e_{2}$ & $\begin{array}{l}4.139(2.363 \\
3.640,6.413)\end{array}$ & $\begin{array}{l}3.930(2.111 \\
3.459,6.218)\end{array}$ & $\begin{array}{r}8.068(4.474 \\
7.100,12.631)\end{array}$ & $\begin{array}{l}0.209(0.251 \\
0.181,0.194)\end{array}$ \\
\hline$e_{3}$ & $\begin{array}{l}3.719(1.943 \\
3.267,5.948)\end{array}$ & $\begin{array}{l}4.162(2.397 \\
3.669,6.420)\end{array}$ & $\begin{array}{c}7.882(4.340 \\
6.936,12.368)\end{array}$ & $\begin{array}{l}-0.443(-0.454 \\
-0.401,-0.473)\end{array}$ \\
\hline$e_{4}$ & $\begin{array}{l}4.877(3.070 \\
4.396,7.167)\end{array}$ & $\begin{array}{l}4.099(2.279 \\
3.594,6.425)\end{array}$ & $\begin{array}{r}8.977(5.349 \\
7.990,13.591)\end{array}$ & $\begin{array}{l}0.778(0.791 \\
0.802,0.742)\end{array}$ \\
\hline$e_{5}$ & $\begin{array}{l}4.115(2.303 \\
3.663,6.379)\end{array}$ & $\begin{array}{l}3.285(1.567 \\
2.810,5.477)\end{array}$ & $\begin{array}{r}7.400(3.870 \\
6.473,11.856)\end{array}$ & $\begin{array}{l}0.830(0.736 \\
0.853,0.902)\end{array}$ \\
\hline$e_{6}$ & $\begin{array}{l}3.753(1.933 \\
3.246,6.080)\end{array}$ & $\begin{array}{l}4.162(2.350 \\
3.687,6.450)\end{array}$ & $\begin{array}{r}7.915(4.283 \\
6.993,12.530)\end{array}$ & $\begin{array}{l}-0.409(-0.417 \\
-0.441,-0.370)\end{array}$ \\
\hline$e_{7}$ & $\begin{array}{l}3.484(1.720 \\
3.018,5.714)\end{array}$ & $\begin{array}{l}3.731(1.888 \\
3.243,6.062)\end{array}$ & $\begin{array}{r}7.215(3.607 \\
6.261,11.776)\end{array}$ & $\begin{array}{l}-0.247(-0.168 \\
-0.224,-0.349)\end{array}$ \\
\hline$e_{8}$ & $\begin{array}{l}4.016(2.167 \\
3.525,6.356)\end{array}$ & $\begin{array}{l}3.854(2.055 \\
3.396,6.111)\end{array}$ & $\begin{array}{r}7.870(4.222 \\
6.920,12.467)\end{array}$ & $\begin{array}{l}0.162(0.112 \\
0.129,0.245)\end{array}$ \\
\hline$e_{9}$ & $\begin{array}{l}4.001(2.137 \\
3.488,6.378)\end{array}$ & $\begin{array}{l}3.990(2.205 \\
3.521,6.244)\end{array}$ & $\begin{array}{r}7.991(4.342 \\
7.009,12.622)\end{array}$ & $\begin{array}{l}0.010(-0.068 \\
-0.034,0.133)\end{array}$ \\
\hline$e_{10}$ & $\begin{array}{l}3.637(1.872, \\
3.177,5.862)\end{array}$ & $\begin{array}{l}4.000(2.147 \\
3.505,6.346)\end{array}$ & $\begin{array}{c}7.637(4.020 \\
6.682,12.208)\end{array}$ & $\begin{array}{l}-0.363(-0.275 \\
-0.329,-0.485)\end{array}$ \\
\hline$e_{11}$ & $\begin{array}{l}3.671 \text { (1.847, } \\
3.204,5.962)\end{array}$ & $\begin{array}{l}3.853(2.053 \\
3.386,6.119)\end{array}$ & $\begin{array}{c}7.524(3.900 \\
6.590,12.081)\end{array}$ & $\begin{array}{l}-0.182(-0.206 \\
-0.183,-0.157)\end{array}$ \\
\hline$e_{12}$ & $\begin{array}{l}3.939(2.094 \\
3.445,6.277)\end{array}$ & $\begin{array}{l}4.384(2.586 \\
3.919,6.648)\end{array}$ & $\begin{array}{c}8.323(4.680 \\
7.364,12.925)\end{array}$ & $\begin{array}{l}-0.446(-0.492 \\
-0.474,-0.371)\end{array}$ \\
\hline
\end{tabular}

Based on this fuzzy DEMATEL, we distinguish the interrelations between each dimension and element by adopting the FINRM for each criterion (see Figure 1). Figure 1 further illustrates influence priority, the market orientation $\left(D_{2}\right)$ affects other criteria, re- 
source orientation $\left(D_{3}\right)$, natural environmental orientation $\left(D_{1}\right)$ and brand orientation $\left(D_{4}\right)$; clearly, market orientation $\left(D_{2}\right)$ shows an important feature and has the strongest impact on other elements. Therefore, administrators need to enhance this first and focus next on resource orientation $\left(D_{3}\right)$, natural environmental orientation $\left(D_{1}\right)$, and brand orientation $\left(D_{4}\right)$; clearly, market orientation $\left(D_{2}\right)$ estimates and enhances the effect of green marketing orientations toward sustainability of the hospitality industry in the COVID-19 pandemic. The result proposes that hospitality industry managers' major concern is market orientation enhancement, as well as inter-functional coordination $\left(e_{4}\right)$, competitor orientation $\left(e_{5}\right)$, and customer orientation $\left(e_{6}\right)$. The specialists suggested that primarily enhancing these elements might be better than doing so for other dimensions.
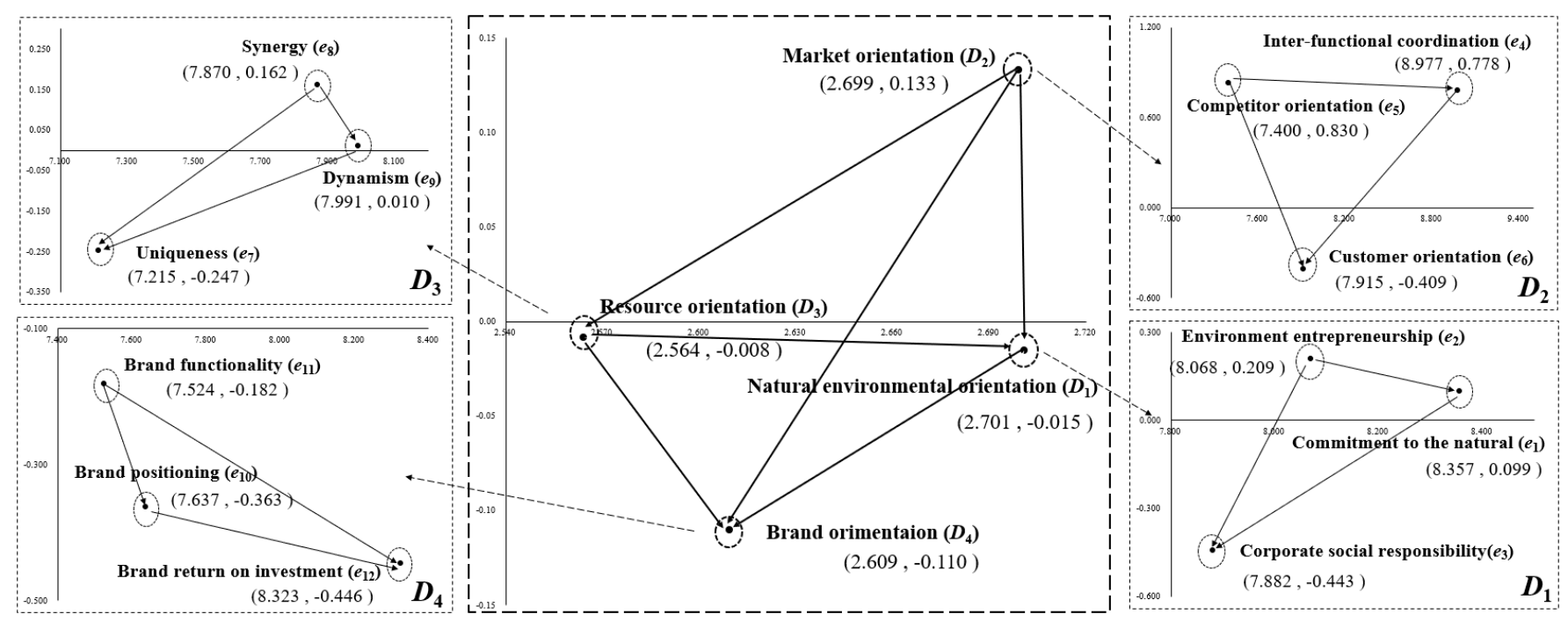

Figure 1. The FINRM for each dimension and element.

In the natural environmental orientation $\left(D_{1}\right)$, environment entrepreneurship $\left(e_{2}\right)$ exerts a direct influence on the other elements, such as commitment to nature $\left(e_{1}\right)$ and corporate social responsibility $\left(e_{3}\right)$. Hospitality industry managers approved that environment entrepreneurship has the most effect and is the best method to enhance green marketing orientation in the COVID-19 pandemic. Furthermore, "customer orientation" $\left(e_{6}\right)$ was considered to be the least influential element or be the last element which needs to be enhanced, from the specialists' perspectives. Hence, the common enhancement priority can be arranged as $\left(e_{5}\right),\left(e_{4}\right),\left(\mathrm{e}_{6}\right)$ in the market orientation $\left(D_{2}\right)$. In the resource orientation $\left(D_{3}\right)$, synergy $\left(e_{8}\right)$ directly affects dynamism $\left(e_{9}\right)$ and uniqueness $\left(e_{7}\right)$, demonstrating which enhancement must be prioritized, $\left(e_{8}\right),\left(e_{9}\right),\left(e_{7}\right)$. In the brand orientation $\left(D_{4}\right)$, brand functionality $\left(e_{11}\right)$ directly affects brand positioning $\left(e_{10}\right)$ and brand return on investment $\left(e_{12}\right)$, demonstrating that the priority for enhancement must be $\left(e_{11}\right),\left(e_{10}\right),\left(e_{12}\right)$. Such an influential subnetwork appears in the separate dimension, as shown in Figure 1. For these managers, these outcomes are not only distinct, but also predigest the distinguishing priorities for the enhancement of intricate elements.

\subsection{The Fuzzy DANP Influential Weight Method}

The fuzzy DEMATEL approach is used to make sure of the influence relations between several dimensions and elements, and then to acquire the most exact weights of influence. The object of the fuzzy DANP is to state these interrelations owing to feedback and inter dependence subjects for the elements. Thus, we gather the quality evaluation pattern, using the fuzzy DANP approach, that is able to then acquire the influence weights for each element (see Table 7). 
Table 7. Fuzzy total influence weight for each dimension/element.

\begin{tabular}{|c|c|c|c|c|c|c|}
\hline Dimensions/Elements & Weight & Rank & Local Weight & Rank & Global Weight & Rank \\
\hline $\begin{array}{l}\text { Natural Environmental } \\
\text { Orientation }\left(D_{1}\right)\end{array}$ & 0.263 & 1 & & & & \\
\hline Commitment to nature $\left(e_{1}\right)$ & & & $\begin{array}{l}0.338(0.337 \\
0.337,0.339)\end{array}$ & 2 & $\begin{array}{l}0.089(0.089 \\
0.089,0.089)\end{array}$ & 3 \\
\hline $\begin{array}{c}\text { Environment } \\
\text { entrepreneurship }\left(e_{2}\right)\end{array}$ & & & $\begin{array}{l}0.320(0.313 \\
0.323,0.325)\end{array}$ & 3 & $\begin{array}{l}0.084(0.082 \\
0.085,0.086)\end{array}$ & 7 \\
\hline $\begin{array}{l}\text { Corporate social } \\
\text { responsibility }\left(e_{3}\right)\end{array}$ & & & $\begin{array}{l}0.342(0.350 \\
0.340,0.335)\end{array}$ & 1 & $\begin{array}{l}0.090(0.092 \\
0.089,0.088)\end{array}$ & 2 \\
\hline Market orientation $\left(D_{2}\right)$ & 0.240 & 3 & & & & \\
\hline $\begin{array}{l}\text { Inter-functional } \\
\text { coordination }\left(e_{4}\right)\end{array}$ & & & $\begin{array}{l}0.360(0.371 \\
0.357,0.350)\end{array}$ & 2 & $\begin{array}{l}0.086(0.089 \\
0.086,0.084)\end{array}$ & 5 \\
\hline Competitor orientation $\left(e_{5}\right)$ & & & $\begin{array}{l}0.278(0.256 \\
0.280,0.299)\end{array}$ & 3 & $\begin{array}{l}0.067(0.061 \\
0.067,0.072)\end{array}$ & 12 \\
\hline Customer orientation $\left(e_{6}\right)$ & & & $\begin{array}{l}0.362(0.373 \\
0.363,0.351)\end{array}$ & 1 & $\begin{array}{l}0.087(0.090 \\
0.087,0.084)\end{array}$ & 4 \\
\hline Resource orientation $\left(D_{3}\right)$ & 0.237 & 4 & & & & \\
\hline Uniqueness $\left(e_{7}\right)$ & & & $\begin{array}{l}0.318(0.306 \\
0.319,0.329)\end{array}$ & 3 & $\begin{array}{l}0.075(0.072 \\
0.075,0.078)\end{array}$ & 11 \\
\hline Synergy $\left(e_{8}\right)$ & & & $\begin{array}{l}0.334(0.335 \\
0.335,0.332)\end{array}$ & 2 & $\begin{array}{l}0.079(0.079 \\
0.079,0.079)\end{array}$ & 10 \\
\hline Dynamism $\left(e_{9}\right)$ & & & $\begin{array}{l}0.348(0.359 \\
0.347,0.339)\end{array}$ & 1 & $\begin{array}{l}0.082(0.085 \\
0.082,0.080)\end{array}$ & 8 \\
\hline Brand orientation $\left(D_{4}\right)$ & 0.261 & 2 & & & & \\
\hline Brand positioning $\left(e_{10}\right)$ & & & $\begin{array}{l}0.324(0.316 \\
0.324,0.332)\end{array}$ & 2 & $\begin{array}{l}0.085(0.083 \\
0.085,0.087)\end{array}$ & 6 \\
\hline Brand functionality $\left(e_{11}\right)$ & & & $\begin{array}{l}0.312(0.303 \\
0.314,0.320)\end{array}$ & 3 & $\begin{array}{l}0.081(0.079 \\
0.082,0.084)\end{array}$ & 9 \\
\hline $\begin{array}{l}\text { Brand return on } \\
\text { investment }\left(e_{12}\right)\end{array}$ & & & $\begin{array}{l}0.364(0.381 \\
0.362,0.348)\end{array}$ & 1 & $\begin{array}{l}0.095(0.099 \\
0.095,0.091)\end{array}$ & 1 \\
\hline
\end{tabular}

Besides, we determine the most significant elements for this estimation of the effect of green marketing orientations toward the sustainability of the hospitality industry. The most important is found in brand return on investment $\left(e_{12}\right)$, with a fuzzy influence weight of 0.095. Next is corporate social responsibility $\left(e_{3}\right)$, where the fuzzy influence weight is 0.090 , which is followed by commitment to nature $\left(e_{1}\right)$, for which the fuzzy influence weight is 0.089. Furthermore, the weights of influence are consolidated, applying the DEMATEL with a fuzzy approach to gauge the precedence of issues to be solved according to the INRM of fuzzy.

\subsection{Discussion}

Primarily, in the order of importance, as illustrated in Figure 1, the priority for enhancement is arranged as: market orientation $\left(D_{2}\right)$, resource orientation $\left(D_{3}\right)$, environmental orientation $\left(D_{1}\right)$, and brand orientation $\left(D_{4}\right)$. This permutation is important for hospitality industry managers. To evaluate the effect of green marketing orientations toward sustainability, hotel managers recognize that market orientation needs to be primarily improved. Efforts in the way will produce a system of influences on the other dimensions and concurrently resolve various issues. The FINRM shown here determines the influence networks beyond a linear association, from either element or dimension opinions.

Subsequently, these elements-including environment entrepreneurship $\left(e_{2}\right)$, interfunctional coordination $\left(e_{4}\right)$, synergy $\left(e_{8}\right)$ and brand functionality $\left(e_{11}\right)$-influence the other elements in the separate dimensions (see Figure 1). Notably, environment entrepreneurship $\left(e_{2}\right)$ has the highest priority because the degree to which the hospitality industry takes 
considered risks is innovative, and it determines proactiveness for sustainability with green orientations. Inter-functional coordination $\left(e_{4}\right)$ and synergy $\left(e_{8}\right)$ also deserves further attention. Therefore, greater inter-functional coordination, synergy, and brand functionality can make it easier to improve the sustainability of the hospitality industry in the COVID-19 pandemic with green marketing orientations.

Next, the most important element considered by DANP for green marketing orientations decisions is brand return on investment $\left(e_{12}\right)$, weighted at 0.095 (see Table 7 ). The greatest effect of green marketing orientations to the hospitality industry is the brand equity of implementation and enhancement. Managers expect greater brand return on investment for green brands, which are very significant for realizing advantage in the market and leveraging this into the financial rewards. Brand return on investment is therefore the most significant element for green marketing orientations towards sustainability in the hospitality industry.

For long-term improvement, managers need to manage motives wisely, as stated above. We specify the research outcomes, our results in Table 8 , in relation to the objective of this research. This study illustrates the effects of the green marketing orientations model toward the sustainability of the hospitality industry. It submits that green marketing orientations can be improved for most hotel managers who use the green marketing orientations model toward sustainability in the COVID-19 pandemic. Nevertheless, decision-makers need to be careful when they apply the model. The importance of the 12 elements might differ based on different results, and managers must compare this green marketing orientations model toward sustainability of the hospitality industry in the COVID-19 pandemic.

Table 8. Priorities for enhancement of green marketing orientations.

\begin{tabular}{cc}
\hline Formula & Range of Enhancement Priorities \\
\hline $\begin{array}{c}\text { Fuzzy influence relations network for the green } \\
\text { marketing orientations }\end{array}$ & $\left(D_{2}\right),\left(D_{3}\right),\left(D_{1}\right),\left(D_{4}\right)$ \\
\hline & $\left(D_{1}\right):\left(e_{2}\right)\left(e_{1}\right)\left(e_{3}\right)$ \\
& $\left(D_{2}\right):\left(e_{5}\right)\left(e_{4}\right)\left(e_{6}\right)$ \\
Influence relations network of elements within & $\left(D_{3}\right):\left(e_{8}\right)\left(e_{9}\right)\left(e_{7}\right)$ \\
individual dimensions & $\left(D_{4}\right):\left(e_{11}\right)\left(e_{10}\right)\left(e_{12}\right)$ \\
\hline
\end{tabular}

\section{Conclusions}

The main purpose of this existing study was to evaluate the interrelations among green marketing orientations through the viewpoint of the most significant green marketing orientations in the framework of the hospitality industry in the COVID-19 pandemic. To attain this objective, an investigation context was established. A literature review on green marketing orientations was conducted, and a validation of the important elements through the multiple viewpoint context through specialists via means of an MCDM approach was carried out. A mixture of fuzzy theory, DEMATEL, and DANP methods was offered for this estimation of green marketing orientations based on dissimilar viewpoints of strategy. The significance and the interrelations of individual elements were offered, and divided for individual dimensions and in aggregated arrangements overall dimensions.

Regarding the implications, management administration has a role in assessing green marketing orientations toward sustainability in the hospitality industry in the COVID19 pandemic through prioritizing and categorizing green marketing orientations toward sustainability evaluation within a green marketing orientations substructure to ensure its actual use for sustainability. The study proposes an easily and comprehensive relevant MCDM model which could be applied to assist in disentangling selection decisions and green marketing orientations formulation in the hospitality industry in the COVID-19 pandemic. The study is focused on the analysis survey-base and multiple elements for green marketing orientation formulas in the Taiwanese hospitality industry in the COVID-19 pandemic. To our understanding, that is the only instance of an approach addressing the green marketing orientations from the viewpoint of hospitality in Taiwan. It is shown that 
green marketing orientations initiatives in Taiwan are generally perceived within a market orientation, rather than within the totality of systemic efforts towards multifaceted issues encompassing natural environmental orientation, resource orientation, and brand orientation viewpoints. Hence, this investigation is significant in that it puts forward and presents explanations of the green marketing orientations common in Taiwan's hospitality industry in the COVID-19 pandemic. A flexible, practical and useful model for determining the hierarchical determinants of a strategic orientations program for the hospitality industry is proposed. These elements are ordered through the fuzzy DEMATEL and fuzzy DANP approaches. While the model presented is universal, the perceptions of green marketing orientations via specialists in Taiwan could be thought to be a limitation. Nevertheless, green marketing orientations, as well as the development of sustainability and the market, are diverse in different regions around the world. Thus, whether the hospitality industry wishes to take advantage of systematic models such as these approaches and proposals, regional applications must be established to enhance competitiveness in the broader market. The model can be improved for application in numerous regions of the world, but conclusions will vary. These conclusions can support managers' proposals for strategic orientation actions which are suited to topographies. A supplementary extension of the study would be a comparison of pairs of green marketing orientations application purposes against those that are more favorable. Such a study can advance the consciousness of these parts most in need of improvement in green marketing orientations development via relating dissimilar implementations.

The dimensions and elements discussed in this research serve as bridging mechanisms which are beneficial for exploring the effect of green marketing orientations toward the sustainability of the hospitality industry in the COVID-19 pandemic. This study would have dissimilar effects on managers in the hospitality industry. Nevertheless, there are numerous limitations to this study, hence the need for further studies. Primarily, the investigation was carried out using group samples with relatively high levels of acquaintance with and knowledge of technology. Our consequences can be validated using large samples to improve these results. Next, the green marketing orientations structure was used for the assessment model. Further studies can engage other multiple element models (such as employee orientation) to estimate the related weights of the influences on green marketing orientations toward the sustainability of the hospitality industry in the COVID-19 pandemic. Lastly, the elements for assessment were inferred, since a review of the green marketing orientations assessment literature excludes some possible influences on green marketing assessment. Future research could use other approaches; for example, longitudinal research and in-depth interviews to comprise the other elements.

Author Contributions: Conceptualization, M.-T.L., C.-Y.H., B.-H.T. and C.-S.C.; Methodology, M.T.L.; Formal analysis, M.-T.L.; Investigation, M.-T.L.; Writing-original draft, M.-T.L.; Writingreview \& editing, M.-T.L.; visualization, M.-T.L.; supervision, M.-T.L.; project administration, C.-Y.H., B.-H.T. and C.-S.C.; funding acquisition, C.-Y.H. All authors have read and agreed to the published version of the manuscript.

Funding: This research received no external funding.

Institutional Review Board Statement: Not applicable.

Informed Consent Statement: Not applicable.

Data Availability Statement: Not applicable.

Conflicts of Interest: The authors declare no conflict of interest.

\section{References}

1. UNWTO. World Tourism Barometer (English Version) Volume 18, No 2; UNWTO: Madrid, Spain, 2020.

2. Bartik, A.W.; Bertrand, M.; Cullen, Z.B.; Glaeser, E.L.; Luca, M.; Stanton, C.T. How Are Small Businesses Adjusting to Covid-19? Early Evidence from a Survey (No. w26989); National Bureau of Economic Research: Cambridge, MA, USA, 2020. 
3. Gössling, S.; Scott, D.; Hall, C.M. Pandemics, tourism and global change: A rapid assessment of COVID-19. J. Sustain. Tour. 2020, 29, 1-20. [CrossRef]

4. Cuesta-Valiño, P.; Rodríguez, P.G.; Núñez-Barriopedro, E. The impact of corporate social responsibility on customer loyalty in hypermarkets: A new socially responsible strategy. Corp. Soc. Responsib. Environ. Manag. 2019, 26, 761-769. [CrossRef]

5. Cuesta-Valiño, P.; Rodríguez, P.G.; Núñez-Barriopedro, E. Perception of Advertisements for Healthy Food on Social Media: Effect of Attitude on Consumers' Response. Int. J. Environ. Res. Public Health 2020, 17, 6463. [CrossRef]

6. Cuesta-Valiño, P.; Bolifa, F.; Núñez-Barriopedro, E. Sustainable, Smart and Muslim-Friendly Tourist Destinations. Sustainability 2020, 12, 1778. [CrossRef]

7. Reyes-Menendez, A.; Saura, J.R.; Thomas, S.B. Exploring key indicators of social identity in the \#MeToo era: Using discourse analysis in UGC. Int. J. Inf. Manag. 2020, 54, 102129. [CrossRef]

8. Lu, M.-T.; Tsai, J.-F.; Shen, S.-P.; Lin, M.-H.; Hu, Y.-C. Estimating sustainable development performance in the electrical wire and cable industry: Applying the integrated fuzzy MADM approach. J. Clean. Prod. 2020, 277, 122440. [CrossRef]

9. Szabo, S.; Webster, J. Perceived Greenwashing: The Effects of Green Marketing on Environmental and Product Perceptions. J. Bus. Ethics 2020, 1-21. [CrossRef]

10. Laroche, M.; Bergeron, J.; Barbaro-Forleo, G. Targeting consumers who are willing to pay more for environmentally friendly products. J. Consum. Mark. 2001, 18, 503-520. [CrossRef]

11. Liou, J.J.H.; Kaklauskas, A.; Lu, M.-T.; Chuang, Y.-C. Improving strategic orientations for promoting hotel services using an integrated rough magdm model. Technol. Econ. Dev. Econ. 2019, 25, 188-218. [CrossRef]

12. Tajeddini, K. Customer orientation, learning orientation, and new service development: An empirical investigation of the Swiss hotel industry. J. Hosp. Tour. Res. 2011, 35, 437-468. [CrossRef]

13. Tajeddini, K.; Trueman, M. Perceptions of innovativeness among Iranian hotel managers. J. Hosp. Tour. Technol. 2014, 5, 62-77. [CrossRef]

14. Tajeddini, K.; Altinay, L.; Ratten, V. Service innovativeness and the structuring of organizations: The moderating roles of learning orientation and inter-functional coordination. Int. J. Hosp. Manag. 2017, 65, 100-114. [CrossRef]

15. Noble, C.H.; Sinha, R.K.; Kumar, A. Market Orientation and Alternative Strategic Orientations: A Longitudinal Assessment of Performance Implications. J. Mark. 2002, 66, 25-39. [CrossRef]

16. Brower, J.; Rowe, K. Where the eyes go, the body follows? Understanding the impact of strategic orientation on corporate social performance. J. Bus. Res. 2017, 79, 134-142. [CrossRef]

17. Fuentes, C. How green marketing works: Practices, materialities, and images. Scand. J. Manag. 2015, 31, 192-205. [CrossRef]

18. Papadas, K.-K.; Avlonitis, G.J.; Carrigan, M. Green marketing orientation: Conceptualization, scale development and validation. J. Bus. Res. 2017, 80, 236-246. [CrossRef]

19. Polonsky, M.J. Transformative green marketing: Impediments and opportunities. J. Bus. Res. 2011, 64, 1311-1319. [CrossRef]

20. Chung, K.C. Green marketing orientation: Achieving sustainable development in green hotel management. J. Hosp. Mark. Manag. 2019, 29, 722-738. [CrossRef]

21. Zadeh, L.A. Fuzzy sets. Inf. Control. 1965, 8, 338-353. [CrossRef]

22. Lu, M.-T.; Hsu, C.-C.; Liou, J.J.; Lo, H.-W. A hybrid MCDM and sustainability-balanced scorecard model to establish sustainable performance evaluation for international airports. J. Air Transp. Manag. 2018, 71, 9-19. [CrossRef]

23. Lu, M.T.; Tzeng, G.H.; Tang, L.L. Environmental strategic orientations for improving green innovation performance in fuzzy environment-Using new fuzzy Hybrid MCDM model. Int. J. Fuzzy Syst. 2013, 15, 297-316.

24. Zhang, X.; Xiu, G.; Shahzad, F.; Duan, Y. Optimal Financing Strategy in a Capital-Constrained Supply Chain with Retailer Green Marketing Efforts. Sustainability 2021, 13, 1357. [CrossRef]

25. Hasan, Z.; Ali, N.A. The Impact of Green Marketing Strategy on the Firm's Performance in Malaysia. Procedia-Soc. Behav. Sci. 2015, 172, 463-470. [CrossRef]

26. Ginsberg, J.M.; Bloom, P.N. Choosing the right green marketing strategy. MIT Sloan Manag. Rev. 2004, 46, 79-84.

27. Jones, P.; Comfort, D.; Hillier, D. What's in store? Retail marketing and corporate social responsibility. Mark. Intell. Plan. 2007, 25, 17-30. [CrossRef]

28. Silayoi, P.; Speece, M. Packaging and purchase decisions: An exploratory study on the impact of involvement level and time pressure. Br. Food J. 2004, 106, 607-628. [CrossRef]

29. Banerjee, S.B. Corporate environmentalism: The construct and its measurement. J. Bus. Res. 2002, 55, 177-191. [CrossRef]

30. Hu, J.W.S.; Hu, Y.C.; Bein, H.C. Constructing a Corporate Social Responsibility Fund Using Fuzzy Multiple Criteria Decision Making. Int. J. Fuzzy Syst. 2011, 13, 195-205.

31. Menguc, B.; Ozanne, L.K. Challenges of the green imperative: A natural resource-based approach to the environmental orientation-business performance relationship. J. Bus. Res. 2005, 58, 430-438. [CrossRef]

32. Qu, R.; Zhang, Z. Market orientation and business performance in MNC foreign subsidiaries-Moderating effects of integration and responsiveness. J. Bus. Res. 2015, 68, 919-924. [CrossRef]

33. Slater, S.F.; Narver, J.C. Market orientation, customer value, and superior performance. Bus. Horiz. 1994, 37, 22-28. [CrossRef]

34. Chen, Y.C.; Li, P.C.; Kenneth, R.E. Effects of interaction and entrepreneurial orientation on organizational performance: In-sights into market driven and market driving. Ind. Mark. Manag. 2012, 41, 1019-1034. [CrossRef]

35. Slater, S.F.; Narver, J.C. Market orientation and the learning organization. J. Mark. 1995, 59, 63-74. [CrossRef] 
36. Narver, J.C.; Slater, S.F. The effect of a market orientation on business profitability. J. Mark. 1990, 54, 20-35. [CrossRef]

37. Barney, J. Firm Resources and Sustained Competitive Advantage. J. Manag. 1991, 17, 99-120. [CrossRef]

38. Prahinski, C.; Kocabasoglu, C. Empirical research opportunities in reverse supply chains. Omega 2006, 34, 519-532. [CrossRef]

39. Collis, D.J.; Montgomery, C.A. Competing on resources: Strategy in the 1990s. Harv. Bus. Rev. 1995, 3, 18-28.

40. Teece, D.J.; Pisano, G.; Shuen, A. Dynamic capabilities and strategic management. Strateg. Manag. J. 1997, 18, 509-533. [CrossRef]

41. Parker, C.M.; Redmond, J.; Simpson, M. A Review of Interventions to Encourage SMEs to Make Environmental Improvements. Environ. Plan. C Gov. Policy 2009, 27, 279-301. [CrossRef]

42. Grant, J. Green marketing. Strateg. Dir. 2008, 24, 25-27. [CrossRef]

43. Polonsky, M.J.; Rosenberger, P.J. Reevaluating green marketing: A strategic approach. Bus. Horizons 2001, 44, 21-30. [CrossRef]

44. Gromark, J.; Melin, F. The underlying dimensions of brand orientation and its impact on financial performance. J. Brand Manag. 2011, 18, 394-410. [CrossRef]

45. Tajeddini, K.; Ratten, V. The moderating effect of brand orientation on inter-firm market orientation and performance. J. Strat. Mark. 2017, 28, 194-224. [CrossRef]

46. Rios, F.J.M.; Martínez, T.L.; Moreno, F.F.; Soriano, P.C. Improving attitudes toward brands with environmental associations: An experimental approach. J. Consum. Mark. 2006, 23, 26-33. [CrossRef]

47. Shrivastava, P. The role of corporations in achieving ecological sustainability. Acad. Manag. Rev. 1995, 20, 936-960. [CrossRef]

48. Büyüközkan, G.; Karabulut, Y.; Mukul, E. A novel renewable energy selection model for United Nations' sustainable devel-opment goals. Energy 2018, 165, 290-302. [CrossRef]

49. Saaty, T.L. Decision Making with Dependence and Feedback: The Analytic Network Process; RWS Publications: Pittsburgh, PA, USA, 1996.

50. Uygun, Ö.; Kaçamak, H.; Kahraman, Ü.A. An integrated DEMATEL and Fuzzy ANP techniques for evaluation and selection of outsourcing provider for a telecommunication company. Comput. Ind. Eng. 2015, 86, 137-146. [CrossRef]

51. Lu, M.T.; Lin, S.W.; Tzeng, G.H. Improving RFID adoption in Taiwan's healthcare industry based on a DEMATEL technique with a hybrid MCDM model. Decis. Support Syst. 2013, 56, 259-269. [CrossRef] 